\title{
The Role of Signaling and Social Identity in Crowdfunding: Evidence from BRICS Countries
}

\author{
Niluh Putu Damayanti, Liyu Adhi Kasari Sulung*
}

\author{
Department of Management, Universitas Indonesia, Depok, Indonesia \\ ${ }^{*}$ Corresponding author.Email: liyu.as@gmail.com
}

\begin{abstract}
This study examines the effect of signaling and the social identity inherent in the project owner in determining the success factor of a crowdfunding project. The study is tested using 580 data from projects in Brazil, Russia, India, China, and South Africa (BRICS countries) during the period from 2012 to the beginning of 2019. Using ordinary least square (OLS) as analysis technique, it is found that the signaling effect that is explained through comments and updates has a positive and significant influence in supporting funding success. Signaling is an ultimate way to eliminate asymmetric information in online transactions including in crowdfunding. Social identity effects on crowdfunding also show positive and significant results in influencing the success of funding explained through the number of project publications on Facebook. Project publication on Facebook is one of the examples of electronic word-of-mouth that has been proven to affect crowdfunding campaigns. On the other hand, it is not proven that the social identity effect explained by the number of friends on Facebook has a significant influence on the success of crowdfunding in the BRICS countries. The number of Facebook friends is long associated with identity sentiment that results in higher funding during the project campaign. However, this research shows no evidence due to some limitations surrounding the data.
\end{abstract}

Keywords: Crowdfunding, Signaling, Social Identity, BRICS, Financing

\section{INTRODUCTION}

In recent years, crowdfunding has become a new channel for funding, particularly for micro-finance that has no access to traditional financial services such as banks and investment agencies (Zhang \& Chen, 2018). The advancement of the Internet through the establishment of social media and the development of online financing platforms shape opportunities for beginner entrepreneurs to raise their capital and at the same time for non-professional investors to invest their money without financial intermediaries (Vismara, 2016). Crowdfunding activities around the world in 2014 alone were able to raise US\$ 16.2 billion, with a growth rate of $167 \%$ (Massolution, 2015). The future of crowdfunding is expected to be yet more radiant in the coming years. By 2020, the economic value of crowdfunding is estimated to reach US\$ 3.2 trillion and able to create two million job opportunities (Fundable, 2014).

The fascination of crowdfunding attracts both scholars and policymakers to build understanding regarding this phenomenon. Many studies have explored subjects related to crowdfunding from various perspectives. These studies include analyzing how crowdfunding works, its generous potential, and possible threats. Previous studies have elaborated the impact of several factors that can be explained concurrently in the framework of signaling theory (Ross, 1977; Spence, 1973). Signaling theory deals with the case when two parties have different access to information as well as their efforts to make the information accessibility equal for both of them (Connelly, Certo, Ireland, \& Reutzel, 2011). Signaling theory, in particular, centers on how to eradicate information asymmetry between parties involved in any transactions (Spence, 2002). Asymmetric information, which mostly occurs in the market, raises an information gap between lenders and borrowers, which is believed to cause the phenomenon called moral hazard (Leland \& Pyle, 1977). With the existence of asymmetric information, every action taken by the market or certain parties will greatly matter considering the important information contained by it (Stiglitz, 2002). Therefore, signaling becomes immensely 
important to deliver information, with no exception in the effort of attracting investors on crowdfunding platforms.

Nevertheless, attracting investors in online forums such as crowdfunding is not easy. Concerning the nature of online transactions, where adequate information regarding fundraisers' profiles is limited, investors will find assessing fundraisers' trustworthiness even harder (Chau, Hu, Lee, \& Au, 2007). Therefore, a bridge in the form of investors' trust is needed so that online transactions could occur (Chien, Chen, \& Wu, 2013). Through signaling, fundraisers deliver information to investors to constitute a sense of trust to invest in the projects owned by fundraisers. This study tries to explain the importance of signaling in determining the success of the crowdfunding campaign.

In addition to signaling, this research will explore the social network aspect of the project owner. Social capital is a valuable resource categorized as intangible capital, but equal to physical and human capital that has a function to support productivity, social capital also performs to do the same as both (Coleman, 1988). The social aspect also benefits the organization because social capital is believed to be able to cut transaction costs by saving the costs incurred for information and coordination (Nahapiet \& Ghoshal, 1998). Social capital provides potential resources in the form of collective support from other individuals in the same network or group (Bourdieu, 1986). Network ownership and social capital have been considered to have important roles in assisting the funding activities of a project (Hsu, 2007). Under the crowdfunding context, the broader the network owned by fundraisers, the higher the probability of the project to achieve its funding goal (Mollick, 2014). This study addresses how social capital owned by project owners can define the success of project funding. Social capital is explored more deeply in social identity, i.e. how one perceives himself as part of a group (Tajfel \& Turner, 1986).

Previous studies have tended to not focus on the geographical location where the project took place. Most of the projects taken into the sample are projects held in developed countries that are based predominantly in North America and Western Europe. This research centers on projects held in developing countries that are members of the BRICS association. Brazil, Russia, India, China, and South Africa (BRICS) lead the economy and political power in emerging countries at regional and international levels. Due to the geographical dimensions and demographic conditions, the BRICS economy is considered capable of influencing global economic development, especially for Low-Income Countries (ILC) (Morazán, Knoke, Knoblauch, \& Scahfer, 2012). While South Africa might not be equal in terms of size and growth of the economy to the other BRICS members, it holds the strongest position with the existence of strong footprints across the African Region, which makes South Africa an exceptional choice as Africa's representative (Thakur, 2014). The BRICS alliance is seen to be a reinforcement for south-south cooperation and representative of important southern regions, namely Africa, Asia, and South America (Sarkar, 2017). Accordingly, this study attempts to comprehend the effect of both signaling and social identity theory on crowdfunding success in BRICS countries.

\section{THEORETICAL BACKGROUND}

\subsection{Reward-based Crowdfunding}

Cruz (2018) defines reward-based crowdfunding as a method that allows the crowd to provide financial assistance for businesses' or individuals' projects, in return for special gifts, appreciation tokens, or the first editions of the products. The idea of reward-based crowdfunding is quite simple and similar to other crowdfunding models. Fundraisers, who need to get funds, advertise their ideas on a crowdfunding platform along with a complete description, needed funds, videos, updates, and, most importantly, an explanation of what types and prizes backers will received (Davidson \& Poor, 2016). A small contribution usually gets a symbolic gift such as the product of the project or the invitation to a particular forum organized by the project owner, while, for sufficiently large contribution, the prizes will vary from the opportunity to meet project owners, the right to contribute ideas for further product development, to recognition as one of the initiators and contributors to the project (Steigenberger, 2017).

\subsection{Crowdfunding in BRICS Countries}

Despite all the hype, crowdfunding success tends to still be a US-centric or, possibly, West-centric phenomenon (Kshetri, 2015). The economic values of crowdfunding in Asia, Africa, and South America are among the smallest compared to other territories such as the US and Western Europe (Massolution, 2015). The growth of crowdfunding platforms in the BRICS countries are $17 \%, 4 \%, 10 \%, 1 \%$, and $4 \%$ for Brazil, Russia, India, China, and South Africa, respectively (World Bank, 2013). Lack of regulation is one of the issues, especially for reward-based and donation-based crowdfunding 
Table I. Crowdfunding Comparisons

\begin{tabular}{|c|c|c|c|c|}
\hline & Growth & Year of Beginning Development & $\begin{array}{l}\text { Leading Crowdfunding } \\
\text { Platforms }\end{array}$ & Regulation \\
\hline Brazil & $17 \%$ & 2010 through the launch of Catarse & $\begin{array}{l}\text { Catarse, Vakinha, Kickante, } \\
\text { and Benfeitora }\end{array}$ & $\begin{array}{l}\text { Limited regulation for investment } \\
\text { crowdfunding, namely equity-based } \\
\text { and lending-based crowdfunding }\end{array}$ \\
\hline Russia & $4 \%$ & 2008 through the launch of Kroogi & $\begin{array}{l}\text { Planeta.ru, Boomstarter.ru, } \\
\text { Rusini, and Tugeza }\end{array}$ & $\begin{array}{l}\text { Central Bank of Russia authorizes the } \\
\text { crowdfunding activity }\end{array}$ \\
\hline India & $10 \%$ & $\begin{array}{l}\text { In } 2010 \text {, some of the crowd-funding } \\
\text { platforms appeared, but the fastest } \\
\text { development started two years after, with } \\
\text { Ketto leading the crowdfunding activity. }\end{array}$ & Ketto and Catapooolt & $\begin{array}{l}\text { Limited regulation for investment } \\
\text { crowdfunding, namely equity-based } \\
\text { and lending-based crowdfunding }\end{array}$ \\
\hline China & $1 \%$ & 2011 through the launch of Demohour & $\begin{array}{l}\text { Demohour, AngleCrunch, } \\
\text { Musikid, Zhongchou, and } \\
\text { Taobao }\end{array}$ & $\begin{array}{l}\text { The Securities of China (SAC) } \\
\text { authorizes the crowdfunding activity. }\end{array}$ \\
\hline $\begin{array}{l}\text { South } \\
\text { Africa }\end{array}$ & $4 \%$ & 2013 through the launch of Thundafund & $\begin{array}{l}\text { Thundafund, Jumpstarter, } \\
\text { and BackaBuddy }\end{array}$ & Out of regulations \\
\hline
\end{tabular}

\subsection{Signaling Theory}

Spence (1973) illustrates the signaling theory under labor market circumstances, where an employer has limited information regarding a candidate's skills and the candidate sends the signal through a good education. The effort of the candidate to provide positive signals through education is one form of reducing asymmetric information between both because signaling is considered to be able to reduce the asymmetric information (Spence, 2002). In signaling theory, one party has more access to information than the other party, which causes the emergence of asymmetric information (Connelly et al., 2011). In addition to reducing asymmetric information between one party and other parties in the market, signaling also plays an important role in strategic formulation (Ndofor \& Levitas, 2004).

Evaluating businesses or projects in the preorganizational stage is a difficult task since there is not enough evidence to assess the owner's credibility and trustworthiness (P. H. Kim, Buffart, \& Croidieu, 2016). Under these circumstances, signaling is needed to help buyers/investors assess the reputation of entrepreneurs. In the crowdfunding context, signaling means displaying special features of the projects that carry important information for backers.

\subsection{Social Capital and Social Identity Theory}

Social capital is the overall potential resources available from networks and social units owned by individuals (Nahapiet \& Ghoshal, 1998). Larance (2001) defines social capital as a public good formed on trust among various groups, thus establishing a network among them. The idea of social capital is distinct from the social network, but both have convergence. The social network is a channel for creating, maintaining, and managing social capital, while social capital is a network able to provide significant information and benefits (Javakhadze, Ferris, \& French, 2016).

Social identity theory suggests human behavior is frequently affected by the choices of identity, which influence the actions and motives behind it (Gerber \& Hui, 2013). Attracting individuals who have "strong identity capital" is a surefire step that is believed to be able to influence the participation of other members within their group (Resnick \& Kraut, 2012). A strong sense of affiliation that lies in identity causes people to move collectively with fellow members of their group (Aaker \& Akutsu, 2009). In the crowdfunding context, this identity power can help the fundraising process due to the emergence of a sense of devotion between backers and fundraisers. Therefore, it is important for fundraisers and funders to identify themselves to those with similar identities so that fundraisers could secure support from them.

\section{HYPOTHESIS DEVELOPMENT}

Hypotheses are developed based on the two theories elaborated above. Signaling effect is informed by signaling theory and social identity effect is informed by social capital and social identity theory. Figure I shows the research model based on both theories formulated previously by Kromidha and Robson (2016). The modification of the research model is made by adding one dependent variable based on the study by Zhang and Chen (2018).

The ability to understand any suggestions, critics, and advice is the key success for an entrepreneur to run a business properly and to generate opportunities (Jack, Dodd, \& Anderson, 2008). In crowdfunding, this ability should help entrepreneurs obtain more opportunities by 
pushing more backers to be involved in their projects. Collecting more backers means recognizing and then reducing the perceived risks backers have on their minds. Perceived risk is caused by uncertainty due to asymmetric information in online transactions and the limitations of backers in evaluating projects before deciding to invest (Li \& Yuan, 2018). Backers can give active signals in the form of their attitude toward the project, while fundraisers respond to the signals to divert and shape the backers' perception of the project (Kromidha \& Robson, 2016). Addressing information that backers send as a signal should help fundraisers recognize opportunities (Jack et al., 2008), while at the same time help fundraisers to reduce perceptions of risk and other misperceptions related to the project. In the end, this signal exchange will make the project more competitive with backers starting to have trust in fundraisers, reflected in the success of project funding.

Signals sent by fundraisers and backers can be shown in the "comment section". If the backers were interested in a crowdfunding project, they would look for more information about the project besides what is already stated in the project description and gather other information regarding the project owner on the platform (Wang, Li, Liang, Ye, \& Ge, 2018). To form their interest, backers will usually leave questions or opinions in the comments section. Similarly, fundraisers send signals through the comment section, the content of which is information related to the project that has not been written by fundraisers in the project description. Providing detailed and reliable information can build trust and at the same time reduce the perception of risk (Li \& Yuan, 2018). Therefore, the first research hypothesis that the authors propose is:

Hypothesis H1: Signals sent by fundraisers and backers through the comment section have a positive influence on crowdfunding success.

Signals sent by fundraisers in the form of progress or information related to the project are another form of involvement in crowdfunding network (Kromidha \& Robson, 2016). The purpose of sending these signals is to keep backers' enthusiasm and inform any information related to the progress of the project (Kickstarter, 2014). In the crowdfunding context, unilateral signals occur in the "update section" because only fundraisers can publish the progress of the project without requiring backer's feedback (Wang et al., 2018). The update is a one-way communication tool that is often used during campaigns because it can accommodate the flexibility to provide additional information about any subjects related to the project campaign (Block, Hornuf, \& Moritz, 2018).

The unilateral signals in crowdfunding, represented by the number of updates, have proven to have a strong influence on crowdfunding success (Block et al., 2018). A project with regular update announcements has a higher probability of success with a rate of $58.7 \%$ compared to projects that never publish any update announcements, with project success rates estimated at only $32.6 \%$ (Xu et al., 2014). Therefore, the second research hypothesis that the authors propose is:

Hypothesis H2: Unilateral signals that fundraiser send through the update section have a positive influence on crowdfunding success.

Social identity theory suggests that self-identity has a strong influence on the motive of people's actions, including giving and supporting others whose identity is similar to them (Gerber, Hui, \& Kuo, 2012). Previous research has revealed that entrepreneurs who declare their profile and identity have a greater chance of success (Tajfel \& Turner, 1986). Investors are considered to pay close attention to the profile of fundraisers, hence, during the fundraising process, fundraisers are required to have similar identities to investors to "engage the crowd" (Gleasure \& Feller, 2016). By using homophily and social identity theory, Muller, Geyer, Soule, and Wafer (2014) predict that many identities come from geography, companies, work groups, or a combination of these elements. One or a combination of them could influence the possibility of voluntary collaboration in social life. Moreover, fundraisers' ability to place their identities on social media, for example, is believed to be able to provide a favorable position for fundraisers when they need mass support (Kromidha \& Robson, 2016). Therefore, the third research hypothesis that the authors propose is:

Hypothesis H3: Fundraisers' identities manifested on social networks have a positive effect on crowdfunding success.

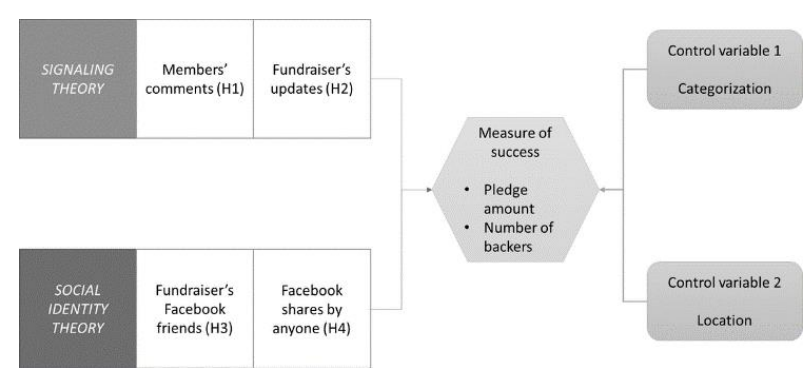

Figure I. RESEARCH MODEL

Social identity theory proposes that community engagement based on identity is necessary to enhance participation (Resnick \& Kraut, 2012). The previous hypothesis recounts fundraisers' identity on social networks. However, we also need to pay attention to backers' identities on their social networks and how their potential sources could support fundraisers' campaign. These resources are available when fundraisers can follow the rule in networking, which is an organic partition where everyone inside is affiliated to share and cooperate (Anderson \& Jack, 2002). On Kickstarter, backers and visitors can show their identity 
by sharing projects on their social networks to help increase the amount of funding on the project campaign through the mechanism called online word-of-mouth that happens outside the fundraiser's social network (Kromidha \& Robson, 2016). The more backers and supporters identify themselves with certain crowdfunding projects, the more new potential backers help the project to fund. Identity-based commitment has eased fundraisers' effort to persuade people to help to campaign for their project, which is associated with a higher probability to succeed compared to other fundraisers without that effort (Hobbs, Grigore, \& Molesworth, 2016). Therefore, the fourth research hypothesis that the authors propose is:

Hypothesis H4: Backers and fundraisers' engagement to the project shown in their social network has a positive effect on crowdfunding success.

\section{DATA COLLECTED AND RESEARCH METHOD}

\subsection{Sampling Process and Data Collection}

Detailed records of 580 projects located in BRICS Countries are extracted from the largest and most popular reward-based crowdfunding platform, Kickstarter. Data gathered only include projects that have campaign duration during 2012 to February 2019. Moreover, projects included in the data are projects whose funding campaign had ended as of February 2019. The projects are further said to be eligible if they succeed to achieve funding goals. The data used are secondary and cross-section data, hence this study cannot offer longitudinal perspective as data used are final figures of crowdfunding projects and do not provide changes over time. However, this study could offer a broad perspective of crowdfunding in BRICS countries since the data used are relatively large, consisting of all project categories and covering nearly all projects available during the five-year collecting period. The data for each country consist of $71,76,117$, 246, and 70 projects for Brazil, Russia, India, China, and South Africa, respectively.
Table II. The Examined Construct of Focal and Control Variables

\begin{tabular}{|c|c|}
\hline Variables & Description and Measurement \\
\hline \multicolumn{2}{|l|}{$\begin{array}{l}\text { Focal } \\
\text { variables }\end{array}$} \\
\hline $\begin{array}{l}\text { Comment } \\
\mathrm{s}\end{array}$ & $\begin{array}{l}\text { The logarithm of number of comments posted by } \\
\text { backers and fundraisers to communicate with other } \\
\text { backers or fundraisers. }\end{array}$ \\
\hline Updates & $\begin{array}{l}\text { The logarithm of number of updates posted by } \\
\text { fundraisers during and after campaign period to } \\
\text { share progress of the project and to create } \\
\text { momentum. }\end{array}$ \\
\hline Friends & $\begin{array}{l}\text { The number of Facebook friends the fundraiser has } \\
\text { who linked directly to fundraisers' profile in } \\
\text { crowdfunding site. The logarithm transformation is } \\
\text { applied for normality. }\end{array}$ \\
\hline Shares & $\begin{array}{l}\text { The logarithm of the number of project shares by } \\
\text { anyone on their Facebook page during and after the } \\
\text { funding period. }\end{array}$ \\
\hline $\begin{array}{l}\text { Pledge } \\
\text { amount }\end{array}$ & $\begin{array}{l}\text { The total amount of money a project earned during } \\
\text { the funding period measured in US dollars. When } \\
\text { the projects use foreign currency, they are converted } \\
\text { to US dollar and then transformed by log function. }\end{array}$ \\
\hline $\begin{array}{l}\text { Number } \\
\text { of backers }\end{array}$ & $\begin{array}{l}\text { Total number of backers supporting a project. Log } \\
\text { transformation is applied for normality }\end{array}$ \\
\hline \multicolumn{2}{|l|}{$\begin{array}{l}\text { Control } \\
\text { variables }\end{array}$} \\
\hline $\begin{array}{l}\text { Project } \\
\text { category }\end{array}$ & $\begin{array}{l}\text { The dummy variables are created for three major } \\
\text { project categories: Art, Technology, and project } \\
\text { categorized as other than Art and Technology }\end{array}$ \\
\hline Location & $\begin{array}{l}\text { The dummy variables are created for five countries } \\
\text { categories: Brazil, Russia, India, China, and South } \\
\text { Africa }\end{array}$ \\
\hline Duration & The logarithm of days in the campaign period \\
\hline
\end{tabular}

\subsection{Measures}

Ordinary least square (OLS) is used to estimate the model. Before running OLS, several analyses are used as predetermined for OLS testing. The analyses include summary statistics and a correlation matrix that allow us to perform multicollinearity test. In the main regression model performed after, the measure of success of crowdfunding has two measurements. The first measure of success is pledge amount (Kromidha \& Robson, 2016) and the second is number of backers (Zhang \& Chen, 2018). Table II shows the detailed descriptions and measurements of key focal and control variables used in this analysis and indicates the constructions of each of them. To test H1, we use members' comments in explaining signaling effect. The independent variable used to test $\mathrm{H} 2$ is fundraiser's updates. The third independent variable to explain social identity effect is fundraiser's Facebook friends. The last independent 
variable used is Facebook shares by anyone, which allows us to test H4. Project categorizations and locations serves as control variables created in dummy form. Campaign duration is appended to the control variable and serves as an additional variable used to perform robustness check in the following section. Table III displays summary statistics and a correlation matrix. The correlation among independent variables are comfortably below 0.8 , which fit the recommended upper limit suggested by Brooks (2014).

Table III. Summary Statistics and Correlation Matrix

\begin{tabular}{|c|c|c|c|c|c|c|c|c|c|c|c|c|c|c|c|c|}
\hline & Mean & SD & 1 & 2 & 3 & 4 & 5 & 6 & 7 & 8 & 9 & 10 & 11 & 12 & 13 & 14 \\
\hline $\begin{array}{l}\text { 1. Pledge } \\
\text { amount }\end{array}$ & 55059.25 & 169067.60 & 1.00 & & & & & & & & & & & & & \\
\hline $\begin{array}{l}\text { 2. Number } \\
\text { of backers }\end{array}$ & 503.54 & 1617.11 & 0.74 & 1.00 & & & & & & & & & & & & \\
\hline 3. Updates & 12.64 & 12.86 & 0.36 & 0.43 & 1.00 & & & & & & & & & & & \\
\hline $\begin{array}{l}4 . \\
\text { Comments }\end{array}$ & 217.87 & 730.56 & 0.79 & 0.76 & 0.46 & 1.00 & & & & & & & & & & \\
\hline 5. Shares & 818.27 & 3173.27 & 0.24 & 0.31 & -0.03 & -0.03 & 1.00 & & & & & & & & & \\
\hline 6. Friends & 1176.58 & 793.67 & -0.03 & -0.02 & 0.20 & 0.30 & 0.05 & 1.00 & & & & & & & & \\
\hline 7. Duration & 32.89 & 11.00 & 0.12 & 0.09 & 0.12 & 0.10 & -0.06 & 0.00 & 1.00 & & & & & & & \\
\hline 8. Brazil & 0.122 & 0.328 & -0.10 & -0.07 & -0.05 & -0.10 & 0.07 & 0.04 & -0.04 & 1.00 & & & & & & \\
\hline 9. Russia & 0.131 & 0.495 & -0.03 & 0.05 & 0.04 & 0.02 & 0.00 & -0.03 & -0.04 & -0.15 & 1.00 & & & & & \\
\hline 10. India & 0.202 & 0.402 & -0.13 & -0.10 & -0.13 & -0.13 & -0.02 & 0.01 & -0.12 & -0.19 & -0.20 & 1.00 & & & & \\
\hline 11. China & 0.424 & 0.338 & 0.24 & 0.12 & 0.16 & 0.21 & 0.06 & -0.10 & 0.21 & -0.32 & -0.33 & -0.43 & 1.00 & & & \\
\hline $\begin{array}{l}\text { 12. South } \\
\text { Africa }\end{array}$ & 0.121 & 0.326 & -0.08 & -0.05 & -0.07 & -0.07 & -0.01 & 0.13 & -0.08 & -0.14 & -0.14 & -0.19 & -0.32 & 1.00 & & \\
\hline 13. Art & 0.516 & 0.500 & -0.26 & -0.23 & -0.30 & -0.28 & -0.12 & 0.18 & -0.14 & 0.15 & 0.01 & 0.20 & -0.34 & 0.11 & 1.00 & \\
\hline $\begin{array}{l}14 . \\
\text { Technology }\end{array}$ & 0.341 & 0.475 & 0.30 & 0.26 & 0.40 & 0.33 & 0.13 & -0.19 & 0.24 & -0.10 & 0.01 & -0.27 & 0.38 & -0.16 & -0.74 & 1.00 \\
\hline $\begin{array}{l}\text { 15. Other } \\
\text { than A\&T }\end{array}$ & 0.143 & 0.350 & -0.03 & -0.02 & -0.11 & -0.05 & 0.00 & 0.00 & -0.13 & -0.08 & -0.03 & 0.08 & -0.03 & 0.06 & -0.42 & $0.29^{-}$ \\
\hline
\end{tabular}

\section{RESULT}

Ordinary least square regression performed in this analysis is tested using robust standard error (robust OLS). Table IV presents the result of regression model for both pledge amount and number of backers as dependent variables. The F-test statistic for all model tested are highly statistically significant at $1 \%$. This reflects all variables taken together have a joint relationship with dependent variables and can explain the phenomenon modeled. Signaling effect depicted by number of comments and updates is statistically and positively significantly related to pledge amount and number of backers, as shown in Models 3 and 6. Thus, $\mathrm{H} 1$ and $\mathrm{H} 2$ are supported. Social identity effect estimated by number of Facebook shares is statistically and positively significant. Thus, $\mathrm{H} 4$ is strongly supported. On the other hand, social identity effect gauged by Facebook friends has not proven to have a relationship to either pledge amount or number of backers. Although it appears with positive coefficient, the result cannot support $\mathrm{H} 3$. 
Table IV. Regression Result

\begin{tabular}{|c|c|c|c|c|c|c|}
\hline & \multicolumn{3}{|c|}{ Dependent variable: pledge amount } & \multicolumn{3}{|c|}{ Dependent variable: number of backers } \\
\hline & $\begin{array}{l}\text { Model 1: } \\
\text { signaling effect }\end{array}$ & $\begin{array}{l}\text { Model 2: social } \\
\text { identity effect }\end{array}$ & $\begin{array}{l}\text { Model 3: main } \\
\text { effect }\end{array}$ & $\begin{array}{l}\text { Model 4: } \\
\text { signaling effect }\end{array}$ & $\begin{array}{l}\text { Model 5: social } \\
\text { identity effect }\end{array}$ & $\begin{array}{l}\text { Model 6: } \\
\text { main effect }\end{array}$ \\
\hline \multicolumn{7}{|l|}{ Signaling effect } \\
\hline \multirow[t]{2}{*}{ Comments } & $0.524 * * *$ & & 0.480 **** & $0.499 * * *$ & & $0.482 * * *$ \\
\hline & $(0.0371)$ & & $(0.0387)$ & $(0.0292)$ & & $(0.0318)$ \\
\hline \multirow[t]{2}{*}{ Updates } & $0.312^{* * *}$ & & $0.256^{* * *}$ & $0.389^{* * * *}$ & & $0.367 * * *$ \\
\hline & $(0.0713)$ & & $(0.0721)$ & $(0.0552)$ & & $(0.0578)$ \\
\hline \multicolumn{7}{|c|}{ Social identity effect } \\
\hline \multirow[t]{2}{*}{ Shares } & & $0.287 * * *$ & $0.132 * * *$ & & $0.252 * * *$ & $0.0710^{* * *}$ \\
\hline & & $(0.0293)$ & $(0.0222)$ & & $(0.0286)$ & $(0.0184)$ \\
\hline \multirow[t]{2}{*}{ Friends } & & $0.137 * *$ & 0.0573 & & 0.075 & 0.0143 \\
\hline & & $(0.0617)$ & $(0.055)$ & & $(0.0533)$ & $(0.0421)$ \\
\hline \multicolumn{7}{|c|}{ Control variables } \\
\hline \multirow[t]{2}{*}{ Brazil } & $-0.607 * *$ & $-0.805 * * *$ & $-0.479 *$ & 0.0644 & -0.335 & 0.213 \\
\hline & $(0.238)$ & $(0.246)$ & $(0.271)$ & $(0.138)$ & $(0.21)$ & $(0.155)$ \\
\hline \multirow[t]{2}{*}{ Russia } & $-0.382 * * *$ & $-0.601 * * *$ & $-0.400 * * *$ & $0.200^{*}$ & -0.0654 & $0.245^{* * *}$ \\
\hline & $(0.14)$ & $(0.198)$ & $(0.132)$ & $(0.116)$ & $(0.198)$ & $(0.112)$ \\
\hline \multirow[t]{2}{*}{ India } & 0.045 & $-0.672 * * *$ & 0.0336 & $0.255^{* *}$ & $-0.439 * * *$ & $0.285^{* *}$ \\
\hline & $(0.164)$ & $(0.165)$ & $(0.166)$ & $(0.122)$ & $(0.159)$ & $(0.132)$ \\
\hline \multirow[t]{2}{*}{ South Africa } & 0.0877 & -0.325 & 0.0091 & $0.310^{* * *}$ & -0.0656 & $0.255^{* * *}$ \\
\hline & (0.17) & (0.198) & $(0.178)$ & $(0.124)$ & $(0.191)$ & $(0.127)$ \\
\hline \multirow[t]{2}{*}{ Art } & $0.395^{* * *}$ & $-1.456^{* * * *}$ & $0.308^{*}$ & 0.498 *** & $-1.367 * * *$ & $0.484 * * *$ \\
\hline & $(0.161)$ & $(0.155)$ & $(0.169)$ & $(0.114)$ & $(0.15)$ & $(0.125)$ \\
\hline \multirow[t]{2}{*}{ Etc. } & 0.0616 & $-1.605 * * *$ & -0.0417 & $0.343^{* *}$ & $-1.325 * * *$ & $0.338^{* * *}$ \\
\hline & $(0.184)$ & $(0.203)$ & $(0.176)$ & $(0.148)$ & $(0.197)$ & $(0.147)$ \\
\hline \multirow[t]{2}{*}{ Constant } & $7.195 * * *$ & $8.357 * * *$ & $6.515 * * *$ & $2.307 * * *$ & $4.117 * * *$ & $1.964 * * *$ \\
\hline & $(0.202)$ & $(0.429)$ & $(0.382)$ & $(0.151)$ & $(0.37)$ & $(0.288)$ \\
\hline R-squared & 0.6398 & 0.4247 & 0.6705 & 0.7183 & 0.3705 & 0.7293 \\
\hline F-stat & 94.03 & 44.01 & 76.9 & 118.28 & 34.79 & 89.61 \\
\hline Prob > F & 0.0000 & 0.0000 & 0.0000 & 0.0000 & 0.0000 & 0.0000 \\
\hline
\end{tabular}

Control dummy variables are performed by excluding one of the two dummy controls for comparison. China and Technology are excluded from the regression for location and project category dummy, respectively. Two of the location control dummy variables are statistically significant, as depicted in Model 3. Projects based in Brazil and Russia are more likely to have lower pledge amount compared to projects based in China. In Model 6, projects based in Russia, India, and South Africa are expected to have higher number of backers compared to projects based in China. Projects categorized as Art are more likely to have higher pledge amount than Technology projects. Projects outside Technology are also estimated to have higher number of backers compared to projects in Technology. 
Table V. Robustness Check

\begin{tabular}{|c|c|c|}
\hline & \multicolumn{2}{|c|}{ Dependent variable } \\
\hline & Pledge amount & Number of backers \\
\hline \multicolumn{3}{|l|}{ Signaling effect } \\
\hline \multirow[t]{2}{*}{ Comments } & $0.479 * * *$ & $0.482 * * *$ \\
\hline & 0.0383 & 0.0317 \\
\hline \multirow[t]{2}{*}{ Updates } & $0.247 * * *$ & $0.363 * * *$ \\
\hline & 0.0734 & 0.0578 \\
\hline \multicolumn{3}{|c|}{ Social identity effect } \\
\hline \multirow[t]{2}{*}{ Shares } & $0.126^{* * *}$ & 0.0683 *** \\
\hline & 0.0214 & 0.0181 \\
\hline \multirow[t]{2}{*}{ Friends } & 0.0673 & 0.0185 \\
\hline & 0.0525 & 0.0411 \\
\hline \multicolumn{3}{|c|}{ Control variables } \\
\hline \multirow[t]{2}{*}{ Days } & $0.602 * * *$ & 0.254 \\
\hline & 0.185 & 0.154 \\
\hline \multirow[t]{2}{*}{ Brazil } & -0.421 & 0.238 \\
\hline & 0.285 & 0.161 \\
\hline \multirow[t]{2}{*}{ Russia } & $-0.325 * *$ & $0.277 * *$ \\
\hline & 0.131 & 0.11 \\
\hline \multirow[t]{2}{*}{ India } & 0.116 & $0.320 * *$ \\
\hline & 0.158 & 0.128 \\
\hline \multirow[t]{2}{*}{ South Africa } & 0.073 & $0.282 * *$ \\
\hline & 0.181 & 0.13 \\
\hline \multirow[t]{2}{*}{$A r t$} & $0.324^{*}$ & $0.490 * * *$ \\
\hline & 0.168 & 0.125 \\
\hline \multirow[t]{2}{*}{ Etc. } & 0.0196 & $0.364 * *$ \\
\hline & 0.18 & 0.151 \\
\hline \multirow[t]{2}{*}{ Constant } & $4.345^{* * * *}$ & $1.048 *$ \\
\hline & 0.777 & 0.601 \\
\hline R-squared & 0.6814 & 0.7317 \\
\hline F-stat & 74.55 & 82.8 \\
\hline Prob $>$ F & 0.0000 & 0.0000 \\
\hline
\end{tabular}

As a form of robustness check, we rerun Models 3 and 6 with the addition of one control variable, namely duration of funding. Table $\mathrm{V}$ summarizes the regression results for robustness check. The results of the two models produce the same result as the previous models when duration is not included. In terms of significance of relationship, both results are still positively and statistically significantly related to pledge amount and number of backers. All of the coefficient determinations show no drastic changes, hence the research models proposed in this study have necessary evidence for structural validity.

\section{DISCUSSIONS}

\subsection{Theoretical Implication}

Previous studies explain signaling theory under various circumstances. Spence (1973) elaborates it under the labor market circumstance, while Akerlof (1970) illustrates it inside the lemon market. Our study deals with signaling theory under the crowdfunding context in which we investigate how signaling could help the crowdfunding mechanism work as required. The first and second hypothesis concern the signaling effect sent by both fundraisers and backers. The first hypothesis focuses on how backers and fundraisers exchange signals eiyh each other through comment sections. The comment section in crowdfunding is used to eliminate information asymmetry that commonly arises in online transactions. Signaling theory offers a solution to eradicate this phenomenon by suggesting market participators send any signals that could lower misperceptions caused by a lack of information. In the case of crowdfunding, backers generally demand various information and investigate a project with questions before deciding to invest their money, considering the uncertainty surrounding crowdfunding (T. Kim, Por, \& Yang, 2017). Signals are sent to persuade backers by arranging solid yet intense communication to deliver any information required (Xiao, Tan, Dong, \& Qi, 2014). Intense communication is built through the available forum in crowdfunding platform where fundraisers and backers could exchange any information. Our finding underlines the importance of direct and interactive communication in the success of crowdfunding financing, supported by previous research by Kromidha and Robson (2016). This result also suggests that financing activities cannot be separated from differences in information accessibility, and the way they choose to deliver and decode the signal (Connelly et al., 2011). The signals sent by both backers and fundraisers are key to another level of commitment in financing, which eventually may strengthen backers' trust in the fundraisers (Li \& Yuan, 2018).

Our second hypothesis places more focus on fundraisers' effort solely. The unilateral signal shows how fundraisers mitigate asymmetric information by distributing a series of project announcements. This signal is delivered by fundraisers through one-way communication inside the update section available on crowdfunding platforms. Our finding confirms previous research that the frequency of announcements published 
by fundraisers is an important signal, which shapes backers' intention to invest in projects (Lagazio \& Querci, 2018). Project announcement is a significant element in maintaining "crowd enthusiasm" to a project because it is the crowd who will define the success of crowdfunding (Steinberg, 2012). Fundraisers spread regular announcements to connect with backers, present new insights about the project, and provide further information about the project itself (Kunz, Bretschneider, Erler, \& Leimeister, 2017). Updates are also crucial as a reminder message that makes the project stand out in the eyes of backers (Kuppuswamy $\&$ Bayus, 2017). These two results certainly support signaling theory and have proven the benefits of signaling effects in reducing asymmetric information while building investors' confidence to invest online.

Our two last hypotheses center on how social identity owned by fundraisers and backers could assist the process of getting funded. The third hypothesis we propose does not support the effect of social identity on crowdfunding. It shows no evidence of relation between social and business network of crowdfunding. Our finding contradicts several studies by Kromidha and Robson (2016), Mollick (2014), and Zheng, Li, Wu, and $\mathrm{Xu}$ (2014), who affirmed that network on social media was able to bring a positive influence to funding. We assume the rejection of this hypothesis is most likely to occur because of several limitations surrounding the availability of data. First, not all projects listed on Kickstarter include links to social media owned by fundraisers. The second limitation is that the popularity of social media in BRICS countries is not identical. In China, for example, the measure of Facebook as a social network is inappropriate since many people use Weibo instead of Facebook. At the same time, the Kickstarter platform only provides Facebook as a social media that can be connected directly to the fundraiser profiles on the platform. Therefore, the third hypothesis is not able to explain appropriately social and business network related to crowdfunding.

Our last hypothesis focuses on the extent to which identity that creates strong social ties could assist in boosting the percentage of successful projects in crowdfunding. We develop the hypothesis based on social identity theory, in which people perceive themselves as members of social groups in the community (Tajfel \& Turner, 1979). Social identity gives fundraisers benefits when their efforts in recruiting and clustering similar members increase participation in projects (Resnick \& Kraut, 2012). Our finding highlights the social identity effect that allows information to circle a particular social network and create strong ties within groups (Kaminski, Hopp, \& Lukas, 2018). This result shows the practical example of social identity theory in which backers support projects that are in line with their identity and aspiration (Aaker $\&$ Akutsu, 2009). Moreover, social identity could serve as peer-evaluation when it comes to convincing potential backers. Peer evaluation is an indispensable element for the decision-making of a potential backer due to the difficulty in evaluating the exact utility of the project given the insufficient information available (Thies, Wessel, \& Benlian, 2014). Peer-evaluation is part of the online word-of-mouth shared through publication on social media. The presence of only wordof-mouth allows users to share experiences and perspectives on a product or service that is likely to influence other consumers to assess its benefits (Hussain et al., 2018). Sharing information through Facebook shares, including sharing crowdfunding projects, is a form of mass personal communication (O'Sullivan \& Carr, 2018), helping the project reach the goal by involving potential backers within the social circles of backers and fundraisers.

To complete our research, we include two control variables in the form of dummies for geographical location and project category. Our results present evidence that projects based in China have higher both pledge and backer amounts compared to other BRICS countries. This may result because the backers' contribution to projects based in China are expectedly higher since projects coming from China are mostly Technology products which require higher pledge. In project category, our result shows projects not categorized as Technology are more likely to have higher pledge amount and backers compared to Technology. This might imply that the backer's contribution to Technology requires a higher price to be paid, resulting that few backers could afford them.

\subsection{Practical Implication}

Findings from this study provide guidelines for several parties involved in crowdfunding practices. First, for small businesses and enterprises, our finding delivers insights for project owners to ensure the aspects and features that influence the success of a project campaign. The uncertainty of online transactions in crowdfunding triggers drawbacks and difficulties due to limited information. Thus, project owners need to make sure the spread of information reaches out to all potential backers. Utilizing website features such as comment and update sections is the cheapest way to avoid asymmetric information and to attract more contributors. Furthermore, project owners could maximize their social circle as well as those of backers to attract more money. Sharing and advertising the project on social media would increase the online wordof-mouth, making the probability of project success increase. Second, this research aims to gain insights not only for fundraisers but also backers. Since we explore the success story of every project we include in the data, this study could help backers in examining which projects have the probability to succeed. Our finding 
also helps backers not to invest in bad projects by elaborating on the success factors of the crowdfunding project. Third, our research helps to give input for the crowdfunding platform to make improvements regarding some features. These features, expectedly, could reduce the project failure rate and increase the percentage of successful projects, while increasing the economic value of crowdfunding. Fourth, this research could provide the path for the development of the crowdfunding platform, especially in regions with small or no access to conventional financial services. Lastly, for the government, this study aims to understand how big is the crowdfunding potential for economic development and to encourage solid regulations for lowering the risk of crowdfunding.

\subsection{Conclusion}

This study aims to examine the success factors in crowdfunding based on factors derived from signaling and social identity theory. Data collected are designed to only include projects from five leading countries in emerging markets to gain insights about how crowdfunding could help fill the financing gap due to limited access to financial services in developing countries. This research finds that signaling effect has positive influence on crowdfunding success. The extent to which backers and fundraisers send signals through comment section positively affects crowdfunding campaign. Backers form their perceptions about the project by reviewing the project and looking for projectrelated information through the comment section. The comment section is an influential forum for fundraisers in providing information or announcing something related to the projects that are not yet available in the project descriptions. Besides comment section, signaling effect is delivered through a series of announcement in the update section. It is found that updates published regularly by fundraisers help the project reach the goal. A series of updates is announced to ensure that the project continues to run and as a form of fundraisers' responsibility to backers.

Our study also confirms the positive influence of social identity effect that is measured by two variables. Nevertheless, the social identity described by the number of friends that fundraisers have on their Facebook accounts does not have a significant effect on crowdfunding success. The social circle has a huge influence on the success of crowdfunding because social identity is deemed to increase self-identity and a sense of belonging among its members. This result could neither accommodate nor confirm previous studies due to some limitations in the data. Our last hypothesis concerning social identity effect explained by the engagement backers and fundraisers have on the project shows different results from the third hypothesis. It is found that community engagement through Facebook shares positively and significantly influences the success of crowdfunding projects. Community engagement encourages backers to not only contribute but also to help promote the project. Backers actively support the campaign process by sharing the project on their social media accounts. This action is the implementation of online word-of-mouth that helps fundraisers receive other potential backers.

\section{REFERENCES}

[1] Aaker, J. L., \& Akutsu, S. (2009). Why do people give? The role of identity in giving. Journal of Consumer Psychology, 19(3), 267-270. https://doi.org/10.1016/j.jcps.2009.05.010

[2] Akerlof, G. A. (1970). The Market for " Lemons ": Quality Uncertainty and the Market Mechanism. The Quarterly Journal of Economics, 84(3), 488500 .

[3] Anderson, A. R., \& Jack, S. L. (2002). The articulation of social capital in entrepreneurial networks: A glue or a lubricant? Entrepreneurship and Regional Development, 14(3), 193-210. https://doi.org/10.1080/08985620110112079

[4] Block, J., Hornuf, L., \& Moritz, A. (2018). Which updates during an equity crowdfunding campaign increase crowd participation? Small Business Economics, 50(1), 3-27. https://doi.org/10.1007/s11187-017-9876-4

[5] Bourdieu, P. (1986). The forms of capital. Handbook of Theory and Research for the Sociology of Education, 241-258. https://doi.org/10.1002/9780470755679.ch15

[6] Brooks, C. (2014). Introductory Economics for Finance. In Cambridge University Press.

[7] Chau, P. Y. K., Hu, P. J. H., Lee, B. L. P., \& Au, A. K. K. (2007). Examining Customers' Trust in Online Vendors and Their Dropout Decisions: An Empirical Study. Electronic Commerce Research and Applications, 6(2), 171-182. https://doi.org/10.1016/j.elerap.2006.11.008

[8] Chien, S.-H., Chen, Y.-H., \& Wu, J.-J. (2013). Building Online Transaction Trust through a TwoStep Flow of Information Communicatio. Journal of Global Information Technology Management, 16(4).

[9] Coleman, J. (1988). Social Capital in the Creation of Human Capital. American Journal of Sociology, 94(1988), 95-120.

[10] Connelly, B. L., Certo, S. T., Ireland, R. D., \& Reutzel, C. R. (2011). Signaling theory: A review 
and assessment. Journal of Management, 37(1), 39-67. https://doi.org/10.1177/0149206310388419

[12] Cruz, J. V. da. (2018). Beyond financing: crowdfunding as an informational mechanism. Journal of Business Venturing, 33(April 2016), 371-393.

[13] Davidson, R., \& Poor, N. (2016). Factors for success in repeat crowdfunding: why sugar daddies are only good for Bar-Mitzvahs. Information Communication and Society, 19(1), 127-139. https://doi.org/10.1080/1369118X.2015.1093533

[14] (2014). Economic Value of Crowdfunding Fundable. Retrieved April 5, 2019, from https://www.fundable.com/learn/resources/infograp hics/economic-value-crowdfunding

[15] Gerber, E. M., \& Hui, J. (2013). Crowdfunding: Motivations and Deterrents for Participation. ACM Transactions on Computing-Human Interaction, 20(6), 34:1-32. https://doi.org/10.1145/2530540

[16] Gerber, E. M., Hui, J. S., \& Kuo, P.-Y. (2012). Crowdfunding: Why people are motivated to post and fund projects on crowdfunding platforms. Proceedings of the International Workshop on Design, Influence, and Social Technologies: Techniques, Impacts and Ethics. Seattle, WA: ACM.

https://doi.org/http://dx.doi.org/10.1145/2530540

[17] Gleasure, R., \& Feller, J. (2016). A Rift in the Ground: Theorizing the Evolution of Anchor Values in Crowdfunding Communities through the Oculus Rift Case Study. Journal of the Association for Information Systems, 17(10), 708-736. https://doi.org/10.17705/1jais.00439

[18] Hobbs, J., Grigore, G., \& Molesworth, M. (2016). Success in the Management of Crowdfunding Projects in the Creative Industries. Internet Research, 26(1), 146-166. https://doi.org/10.1108/IntR-08-2014-0202

[19] Hsu, D. H. (2007). Experienced Entrepreneurial Founders, Organizational Capital, and Venture Capital Funding. Research Policy, 36, 722-741. https://doi.org/10.1016/j.respol.2007.02.022

[20] Hussain, S., Guangju, W., Jafar, R. M. S., Ilyas, Z., Mustafa, G., \& Jianzhou, Y. (2018). Consumers' online information adoption behavior: Motives and antecedents of electronic word of mouth communications. Computers in Human Behavior, 80 , 22-32. https://doi.org/10.1016/j.chb.2017.09.019

[21] Jack, S., Dodd, S. D., \& Anderson, A. R. (2008). Change and The Development of Entrepreneurial
Networks over Time: A Processual Perspective. Entrepreneurship and Regional Development, 20(2),

$125-159$

https://doi.org/10.1080/08985620701645027

[22] Javakhadze, D., Ferris, S. P., \& French, D. W. (2016). Social Capital , Investments , and External Financing. Journal of Corporate Finance, 37, 3855.

[23] Kaminski, J., Hopp, C., \& Lukas, C. (2018). Who benefits from the wisdom of the crowd in crowdfunding? Assessing the benefits of usergenerated and mass personal electronic word of mouth in computer-mediated financing. Journal of Business Economics, 88(9), 1133-1162. https://doi.org/10.1007/s11573-018-0899-3

[24] Kickstarter. (2014). Communicating with backers - Kickstarter. Retrieved April 18, 2019, from https://www.kickstarter.com/help/handbook/update

[25] Kim, P. H., Buffart, M., \& Croidieu, G. (2016). TMI: Signaling Credible Claims in Crowdfunding Campaign Narratives. Group and Organization Management, 41(6), 717-750. https://doi.org/10.1177/1059601116651181

[26] Kim, T., Por, M. H., \& Yang, S.-B. (2017). Winning the Crowd in Online Fundraising Platforms: The Roles of Founder and Project Features. Electronic Commerce Research and Applications, 25, 86-94. https://doi.org/10.1016/j.elerap.2017.09.002

[27] Kromidha, E., \& Robson, P. (2016). Social identity and signalling success factors in online crowdfunding. Entrepreneurship and Regional Development, 28(9-10), 605-629. https://doi.org/10.1080/08985626.2016.1198425

[28] Kshetri, N. (2015). Success of Crowd-based Online Technology in Fundraising: An Institutional Perspective. Journal of International Management, 21(2), $100-116$

https://doi.org/10.1016/j.intman.2015.03.004

[29] Kunz, M. M., Bretschneider, U., Erler, M., \& Leimeister, J. M. (2017). An Empirical Investigation of Signaling in Reward-based Crowdfunding. In Electronic Commerce Research (Vol. 17). https://doi.org/10.1007/s10660-0169249-0

[30] Kuppuswamy, V., \& Bayus, B. L. (2017). [1]Journal of Business Venturing, 32(1), 72-89. https://doi.org/10.1016/j.jbusvent.2016.10.004

[31] Lagazio, C., \& Querci, F. (2018). Exploring the multi-sided nature of crowdfunding campaign 
success. Journal of Business Research, 90(November 2017), 318-324. https://doi.org/10.1016/j.jbusres.2018.05.031

[32] Larance, L. Y. (2001). Fostering Social Capital Through NGO Design: Grameen Bank Membership in Bangladesh. International Social Work, 44(1), 7-18.

[33] Leland, H. E., \& Pyle, D. H. (1977). Informational Asymmetries, Financial Structure, and Financial Intermediation. The Journal of Finance, 32(2), 371-387. Retrieved from http://www.jstor.org/stable/2326770\%5Cnhttp://w ww.jstor.org/stable/2326770\%5Cnhttp://www.jstor .org/stable/2326770\%5Cnhttp://www.jstor.org/stab le/2326770

[34] Li, W., \& Yuan, Y. (2018). Purchase experience and involvement for risk perception in online group buying. Nankai Business Review International, 9(4), 587-607. https://doi.org/10.1108/NBRI-112017-0064

[35] Massolution. (2015). The Crowdfunding Industry Report - 2015CF. Massolution, 1-97. Retrieved from

http://www.crowdsourcing.org/editorial/2013cf-

the-crowdfunding-industry-report $/ 25107$

[36] Mollick, E. (2014). The dynamics of crowdfunding: An exploratory study. Journal of Business Venturing, 29(1), 1-16.

[37] Morazán, P., Knoke, I., Knoblauch, D., \& Scahfer, T. (2012). The Role of Brics in the Developing World. https://doi.org/10.2861/75486

[38] Muller, M., Geyer, W., Soule, T., \& Wafer, J. (2014). Geographical and Organizational Commonalities in Enterprise Crowdfunding. Proceedings of the 17th ACM Conference on Computer Supported Cooperative Work \& Social Computing, 778-789. https://doi.org/10.1145/2531602.2531716

[39] Nahapiet, J., \& Ghoshal, S. (1998). Social Capital , Intellectual Capital, and the Organizational Advantage. Academy of Management Review, 23(2), 242-266. https://doi.org/10.2307/259056

[40] Ndofor, H. A., \& Levitas, E. (2004). Signaling the strategic value of knowledge. Journal of Management, $\quad 30(5), \quad 685-702$. https://doi.org/10.1016/j.jm.2004.04.002

[41] O’Sullivan, P. B., \& Carr, C. T. (2018). Masspersonal communication: A model bridging the mass-interpersonal divide. New Media and Society, 20(3), 1161-1180. https://doi.org/10.1177/1461444816686104
[42] Resnick, P., \& Kraut, R. E. (2012). Building Successful Online Communities: Evidence-Based Social Design: Introduction. MIT Press, 1-17. https://doi.org/10.1016/B978-0-323-393966.00001-4

[43] Ross, S. A. (1977). The Determination of Financial Structure: The Incentive-Signalling Approach. The Bell Journal of Economics, 8(1), 23-40.

[44] Sarkar, U. (2017). Brics: An Opportunity for a Transformative South? South Asian Survey, 21(12), $127-137$. https://doi.org/10.1177/0971523115592495

[45] Spence, Michael. (2002). Signaling in Retrospect and the Informational Structure of Markets. American Economic Review, 92(3), 434-459. https://doi.org/10.1257/00028280260136200

[46] Spence, Micheal. (1973). Job Market Signaling. The Quarterly Journal of Economics, 87(3), 355374.

[47] Steigenberger, N. (2017). Why supporters contribute to reward-based crowdfunding. International Journal of Entrepreneurial Behaviour and Research, 23(2), 336-353. https://doi.org/10.1108/IJEBR-04-2016-0117

[48] Steinberg, D. (2012). The Kickstarter Handbook: Real-Life Success Stories of Artists, Inventors, and Entrepreneurs.

[49] Stiglitz, J. E. (2002). Information and the Change in the Paradigm in Economics. American Economic Review, 92(3), 460-501.

[50] Tajfel, H., \& Turner, J. C. (1979). An Integrative Theory of Intergroup Conflict. The Social Psychology of Intergroup Relations, 33-47.

[51] Tajfel, H., \& Turner, J. C. (1986). The social Theory of Intergroup Behaviour. Psychology of Intergroup Relation, 7-24.

[52] Thakur, R. (2014). How representative are brics? Third World Quarterly, 35(10), 1791-1808. https://doi.org/10.1080/01436597.2014.971594

[53] Thies, F., Wessel, M., \& Benlian, A. (2014). Understanding the dynamic interplay of social buzz and contribution behavior within and between online platforms-evidence from crowdfunding. Proceedings of the 35th International Conference on Information Systems, pp. 1-18. Retrieved from https://aisel.aisnet.org/icis2014/proceedings/Social Media/7/

[54] Vismara, S. (2016). Equity retention and social network theory in equity crowdfunding. Small 
Business Economics, 46(4), 579-590. https://doi.org/10.1007/s11187-016-9710-4

[55] Wang, N., Li, Q., Liang, H., Ye, T., \& Ge, S. (2018). Understanding the importance of interaction between creators and backers in crowdfunding success. Electronic Commerce Research and Applications, 27, 106-117. https://doi.org/10.1016/j.elerap.2017.12.004

[56] Xiao, S., Tan, X., Dong, M., \& Qi, J. (2014). How to Design Your Project in the Online Crowdfunding Market? Evidence from Kickstarter. Thirty Fifth International Conference on Information Systems, Auckland 2014, 1-7. https://doi.org/10.1016/S1081-1206(10)61550-5
[57] Xu, A., Yang, X., Rao, H., Fu, W.-T., Huang, S.W., \& Bailey, B. P. (2014). Show me the money! An analysis of project updates during crowdfunding campaigns. Conference on Human Factors in Computing Systems - Proceedings, 591600. https://doi.org/10.1145/2556288.2557045

[58] Zhang, H., \& Chen, W. (2018). Crowdfunding technological innovations: Interaction between consumer benefits and rewards. Technovation, (May). https://doi.org/10.1016/j.technovation.2018.05.001

[59] Zheng, H., Li, D., Wu, J., \& Xu, Y. (2014). The role of multidimensional social capital in crowdfunding: A comparative study in China and US. Information and Management, 51(4), 488-496. https://doi.org/10.1016/j.im.2014.03.003 